\title{
PENGARUH KARAKTERISTIK INDIVIDU TERHADAP PRODUKTIVITAS KARYAWAN BAGIAN REDAKSI PADA PT. MASA KINI MANDIRI DI BANDAR LAMPUNG
}

\author{
Fitri Handayani $^{(1)}$, Trisnowati Josiah(2), Iwan Zulfikar ${ }^{(3)}$ \\ Fakultas Ekonomi Universitas Sang Bumi Ruwa Jurai \\ handayani.fitri89@gmail.com,trisnowati.josiah@fe.saburai.ac.id,iwan.zulfikar@fe.saburai.ac.id
}

\begin{abstract}
Abstrak. Perusahaan merupakan penggerak perekonomian suatu negara. memiliki andil sebagai penyumbang pendapatan negara melalui pajak yang dibayar oleh perusahaan ,sumber daya manusia merupakan salah satu elemen yang penting bagi perusahaan,karena manusia merupakan penggerak dalam perusahaan. Penelitian ini bertujuan untuk mengetahui pengaruh karakteristik individu terhadap produktivitas karyawan bagian redaksi pada PT. Masa Kini Mandiri di Bandar Lampung. Hasil uji hipotesis menunjukan masing-masing variabel karakteristik individu karyawan $(\mathrm{X})$ memiliki nilai $\mathrm{t}$ hitung $>$ nilai $\mathrm{t}$ tabel yaitu, Usia $(5,998>t$ tabel $(2,007)$, Jenis kelamin $(3,963)>t$ tabel $(2,007)$, Status pernikahan $(2,319)>t$ tabel $(2,007)$, Jumlah tanggungan $(2,655)>t$ tabel $(2,007)$, Pengalaman kerja $(6,275)>t$ tabel $(2,007)$ maka ho ditolak dan ha diterima. Sehingga dapat disimpulkan bahwa terdapat pengaruh antara karakteristik individu (usia, jenis kelamin, status penikahan, jumlah tanggungan, dan pengalaman kerja) terhadap produktivitas karyawan. Berdasarkan hasil uji regresi linear berganda, yaitu: $\mathrm{Y}=53,314+0,454 \mathrm{x}_{1}$, $+0,386 x_{2}+0,273 x_{3}+0,100 x_{4}+0,545 x_{5}$, dari penelitian ini bahwa ada pengaruh yang positif karakteristik individu karyawannya khususnya mengenai usia dan pengalaman kerja karyawan,karena variabel ini berpengaruh secara signifikan terhadap produktivitas karyawan.
\end{abstract}

Kata kunci: Individu, Karakteristik, Pegawai, Produktivitas.

\section{PENDAHULUAN}

Perusahaan merupakan penggerak perekonomian suatu negara. Perusahaan memiliki andil sebagai penyumbang pendapatan negara melalui pajak yang dibayar oleh perusahaan, semakin besar profit yang dihasilkan perusahaan maka semakin besar juga pajak yang dibayar kepada negara. Untuk mendapatkan profit yang besar perusahaan harus bisa memaksimalkan seluruh elemen-elemen yang ada pada perusahaan tersebut. Sumber daya manusia merupakan salah satu elemen yang penting bagi perusahaan, karena manusia merupakan penggerak dalam perusahaan.

Dengan adanya sumber daya manusia yang berkualitas maka perusahaan menjadi lebih mudah dalam mencapai tujuan perusahaan. Tujuan ini akan sangat sulit tercapai jika sumber daya manusia yang dimiliki perusahaan kurang berkualitas atau kurang cakap.

Menurut Jahrie dan Hariyono (2008), Sumber daya manusia merupakan satusatunya unsur yang memiliki akal, perasaan, keinginan, kemampuan, keterampilan, pengetahuan, dorongan, dan daya karya. Semua potensi SDM tersebut berpengaruh terhadap upaya oganisasi untuk mencapai tujuan. Manajemen sumber daya manusia menjadi sebuah menjadi solusi yang tepat bagi perusahaan untuk meningkatkan produktivitas karyawan yang ada dalam perusahaan tersebut.

Menurut Hasibuan (2008), Manajemen sumber daya manusia adalah ilmu dan seni mengatur hubungan dan peranan tenaga kerja agar efektif dan efesien membantu terwujudnya tujuan perusahaan, karyawan, dan masyarakat. Berdasarkan pengertian 
tersebut dapat diketahui bahwa manajemen sumber daya manusia tidak hanya merupakan sebuah ilmu, tapi juga merupakan seni dalam mengatur hubungan karyawan yang ada dalam perusahaan, karena manusia merupakan makhluk yang memiliki hati dan perasaan maka seorang manajer personalia harus mampu melakukan pendekatan secara manusiawi kepada karyawannya.

Kontribusi karyawan bagi perusahaan sangat dominan, karena karyawan adalah penghasil kerja bagi perusahaan. Hal ini berarti adalah setiap pekerjaan dalam perusahaan selalu dilaksanakan oleh karyawan. Keberhasilan suatu perusahaan ditentukan oleh unsur manusia yang melakukan pekerjaan sehingga perlu adanya balas jasa terhadap karyawan sesuai dengan sifat dan keadaannya. Seorang karyawan perlu diperlakukan dengan baik agar karyawan tetap bersemangat dalam bekerja. Pimpinan perusahaan dituntut untuk memperlakukan karyawan dengan baik dan memandang mereka sebagai manusia yang mempunyai kebutuhan baik materi maupun non materi.

Pimpinan perusahaan juga perlu mengetahui, menyadari dan berusaha memenuhi kebutuhan karyawannya, sehingga karyawan dapat bekerja sesuai dengan harapan perusahaan. Di sisi lain, karyawan sebagai motor penggerak perusahaan dituntut untuk bekerjadengan lebih bersemangat agar mampu menghadapi persaingan, dan dapat mempertahankan keberadaan perusahaan. Kemampuan, kecakapan, dan keterampilan karyawan tidak ada artinya bagi perusahaan jika mereka tidak mau bekerja keras dengan menggunakan kemampuan, kecakapan, dan keterampilan yang dimilikinya. Oleh karena itu keberadaan karyawan di dalam perusahaan harus diperhatikan dan di bina seefektif dan seefesien mungkin agar mereka memberikan kemampuan yang terbaik untuk perusahaan di tempat mereka bekerja.

Menurut Hasibuan (2008), Karyawan adalah penjual jasa (pikiran dan tenaganya) dan mendapatkan kompensasi yang besarnya telah ditetapkan sebelumnya. Karyawan yang cakap, mampu, terampil, belum mampu menjamin produktivitas karyawan tersebut akan baik, jika moral kerjanya buruk. Mereka baru bermanfaat dan mendukung terwujudnya tujuan perusahaan jika mereka berkeinginan tinggi untuk berprestasi dalam perusahaan. Karyawan berperan aktif dalam menetapkan rencana, sistem, dan tujuan yang ingin dicapai oleh perusahaan. Karyawan, selain sumber daya manusia yang sangat menentukan keberhasilan suatu organisasi, disisi lain juga sebagai makhluk yang mempunyai pikiran, perasaan, kebutuhan dan harapan-harapan tertentu.

Hal ini sangat memerlukan perhatian tersendiri karena faktor-faktor tersebut akan mempengaruhi prestasi, dedikasi dan loyalitas serta kecintaan terhadap pekerjaan dan perusahaannya. Setiap manusia memiliki karakteristik individu yang berbeda antara satu dengan yang lainnya. Karakteristik- karakteristik ini sangat beragam, setiap perusahaan tentunya dapat memilih seorang karyawan yang mempunyai kriteria yang baik dan karakteristik ini juga harus sesuai dengan apa yang diinginkan perusahaan, karena ketepatan dalam memilih karyawan akan memberikan dampak yang besar bagi kemajuan perusahaan itu sendiri.

Karakter yang baik dari seorang karyawan akan membuatnya lebih mudah dalam melakukan atau menyelesaikan pekerjaan yang dibebankan oleh perusahaan, sedangkan karakter yang kurang baik akan membuat karyawan sulit untuk menyelesaikan pekerjaan yang dibebankan, karena karakter yang buruk akan memberikan impact buruk terhadap 
pekerjaan yang dibebankan, dengan kata lain kedua karakter atau perilaku karyawan ini akan berpengaruh terhadap produktivitas karyawan yang bersangkutan.

Produktivitas juga merupakan hasil kerja yang dapat dicapai oleh seseorang atau sekelompok dalam suatu organisasi, sesuai dengan wewenang dan tanggung jawab masing-masing dalam rangka mencapai tujuan organisasi yang bersangkutan secara legal, tidak melanggar hukum dan sesuai moral maupun etika. Karakteristik individu dalam perusahaan menjadikan pencapain target yang diberikan kepada individu tersebut menjadi beragam, ada individu yang mampu menyelesaikan tugasnya dengan baik ada juga yang dapat menyelesaikan tugasnya dengan kurang baik.

Penelitian ini dilakukan pada PT. Masakini Mandiri, yang beralamat di $\mathrm{Jl}$. Soekarno-Hatta No. 108 Bandar Lampung, merupakan salah satu perusahaan yang bergerak dalam bidang percetakan media massa. PT. Masakini Mandiri memiliki cakupan pekerjaan yang luas, memperkerjakan tenaga kerja dalam jumlah yang cukup besar, dan juga telah menggunakan peralatan mesin yang maju. Untuk mempermudah wilayah kerjanya, PT. Masakini Mandiri membagi struktur kerjanya menjadi dua bagian yaitu bagian usaha dan bagian redaksi, yang pada setiap bagiannya memiliki divisi masing-masing.

Bagian redaksi merupakan salah satu bagian yang penting dalam perusahaan karena bertanggung jawab melaksanakan tugas dan mengkoordinir serta menyaring berita yang akan diangkat. Seluruh karyawan pada bagian redaksi ini sangat menentukan dalam kelancaran kegiatan penerbitan surat kabar Lampung Post setiap harinya, sehingga perlu diperhatikan segala hal yang dapat meningkatkan produktivitas karyawannya, seperti karakteristik individu karyawannya, karena setiap karyawan memiliki karakter, kemampuan, perasaan dan pengharapan yang berbeda untuk diri mereka, karena alasan tersebut maka penelitian ini hanya dilakukan pada bagian redaksi pada PT. Masakini Mandiri.

Berdasarkan latar belakang yang telah dikemukan di atas dan dengan adanya karaktersitik individu karyawan bagian redaksi pada PT. Masakini Mandiri, maka penelitian ini difokuskan pada : "Pengaruh Karakteristik Individu terhadap Produktivitas Karyawan Bagian Redaksi pada PT. Masakini Mandiri di Bandar Lampung"

\section{KAJIAN TEORI}

\section{Pengertian Karakteristik Individu}

Sumber daya yang terpenting dalam organisasi adalah sumber daya manusia, orang-orang yang memberikan tenaga, bakat, kreativitas, dan usaha mereka kepada organisasi agar suatu organisasi dapat tetap eksistensinya. Setiap manusia memiliki karakteristik individu yang berbeda antara satu dengan yang lainnya. Berikut ini beberapa pendapat mengenai karakteristik individu.

Robbins (2009) menyatakan, faktorfaktor yang mudah didefinisikan dan tersedia, data yang dapat diperoleh sebagian besar dari informasi yang tersedia dalam berkas personalia seorang pegawai mengemukakan karakteristik individu meliputi usia, jenis kelamin, status pernikahan, banyaknya tanggungan dan pengalaman kerja dalam organisasi.

Siagian (2008), menyatakan bahwa, Karakteristik biografikal (individu) dapat dilihat dari umur, jenis kelamin, status perkawinan, jumlah tanggungan dan masa kerja. Menurut Morrow (2005), menyatakan bahwa, komitmen organisasi dan kinerja karyawan dipengaruhi oleh karakter personal (individu) yang mencakup usia, masa kerja, pendidikan dan jenis kelamin. 
Berdasarkan pengertian dari para ahli diatas maka karakteristik individu yang akan diteliti pada penelitian ini mencakup usia, jenis kelamin, keahlian, pendidikan, dan pengalaman kerja.

\section{Faktor-faktor Karakteristik Individu}

Ada beberapa faktor dari karakteristik individu menurut Robbins (2009), antara lain:

a. Usia

Robbins (2009) menyatakan bahwa, semakin tua usia pegawai, makin tinggi komitmennya terhadap organisasi, hal ini disebabkan karena kesempatan individu untuk mendapatkan pekerjaan lain menjadi lebih terbatas sejalan dengan meningkatnya usia. Keterbatasan tersebut dipihak lain dapat meningkatkan persepsi yang lebih positif mengenai atasan sehingga dapat meningkatkan kinerja mereka terhadap organisasi.

\section{b. Jenis Kelamin}

Menurut Robbins (2009) Sebagai
makhluk Tuhan Yang Maha Esa,
manusia dibedakan menurut jenis
kelaminnya yaitu pria dan wanita.
Robbins menyatakan bahwa, tidak ada
perbedaan yang konsisten antara pria dan
wanita dalam kemampuan memecahkan
masalah, ketrampilan analisis, dorongan
kompetitif, motivasi, sosiabilitas atau
kemampuan belajar.

c. Status Pernikahan

Robbins (2009) mengatakan Perkawinan memaksakan peningkatan tanggung jawab yang membuat suatu pekerjaan yang tetap menjadi lebih berharga dan penting. Seseorang yang telah menikah merasa lebih mantap dengan pekerjaannya yang sekarang, hal ini dikarenakan bahwa mereka melihat sebagai jaminan untuk masa depannya. Karyawan yang menikah akan lebih sedikit absensinya, tingkat perputaran tenaga kerja yang rendah, dan lebih puas dengan pekerjaan mereka daripada rekan kerjanya yang masih bujangan atau lajang. Besar kemungkinannya bahwa karyawan yang tekun dan puas terhadap pekerjaannya terdapat pada karayawan yang telah menikah.

\section{d. Jumlah Tanggungan}

Jumlah tanggungan merupakan banyaknya orang atau anggota keluarga yang ditanggung oleh seorang karyawan. Semakin banyak jumlah tanggungan seorang karyawan maka akan semakin besar tingkat ketergantungan terhadap perusahaan. Seorang yang memiliki tanggungan akan merasa bahwa pekerjaan mereka akan sangat berharga dan menjadi sangat penting, karena penghasilan yang diperoleh dari pekerjaan tersebut akan digunakan untuk menghidupi anggota keluarga yang menjadi tanggungan mereka.

\section{e. Pengalaman Kerja}

Menurut Jahrie dan Hariono (1999), Pengalaman kerja adalah waktu yang digunakan oleh seseorang untuk memperoleh pengetahuan, keterampilan, dan sikap sesuai dengan tugas yang di bebankan. Kreitner dan Kinicki (2004) menyatakan bahwa, Masa kerja yang lama akan cenderung membuat seorang pegawai lebih merasa betah dalam suatu organisasi, hal ini disebabkan diantaranya karena telah beradaptasi dengan lingkungannya yang cukup lama sehingga seorang pegawai akan merasa nyaman dengan pekerjaannya. Penyebab lain juga dikarenakan adanya kebijakan dari instansi atau perusahaan mengenai jaminan hidup di hari tua. Menurut Kreitner dan Kinicki (2004) Faktorfaktor yang dapat mempengaruhi pengalaman kerja seseorang adalah 
waktu, frekuensi, jenis tugas, penerapan, dan hasil.

\section{Produktivitas Kerja}

Salah satu ukuran yang dapat digunakan oleh pemimpin dalam menilai kemampuan pegawai dalam melaksanakan tugasnya dapat dilihat dari tingkat produktivitas kerja yang dicapai oleh pegawai tersebut. Pengertian produktivitas sebenarnya menyangkut aspek yang luas, yaitu modal (termasuk lahan), biaya, tenaga kerja, energi, alat, dan teknologi. Secara umum, produktivitas merupakan perbandingan antara keluaran (output) yang dicapai dengan masukan (input) yang diberikan. Produktivitas juga merupakan hasil dari efisien. Berikut ini pengertian produktivitas kerja menurut para ahli.

Menurut

Sinungan (2008)

Produktivitas kerja adalah suatu perbandingan antara hasil keluaran dan masukan atau output : input. Masukan sering dibatasi dengan masukan tenaga kerja, sedang keluaran diukur dalam kesatuan fisik bentuk dan nilai.

Menurut Ravianto (2007) dalam bukunya "Produktivitas dan Manajemen" Produktivitas tenaga kerja sebagai suatu konsep yang menunjukan adanya kaitan antara hasil output dengan waktu yang dibutuhkan untuk menghasilkan suatu produk dari seorang tenaga kerja, maksudnya produktivitas seorang tenaga kerja sangat berkaitan dengan hasil kerja yang diperoleh terhadap waktu yang diperlukan untuk menghasilkannya.

Menurut Siagian (2008) Produktivitas kerja merupakan kemampuan memperoleh manfaat dari sarana dan prasarana yang tersedia dengan menghasilkan keluaran (output) yang optimal, bahkan kalau mungkin maksimal. Kemampuan yang dimaksud dalam defenisi tersebut tidak hanya berhubungan dengan sarana dan prasarana, tetapi juga berhubungan dengan pemanfaatan waktu dan sumber daya manusia.

Menurut Hasibuan

Produktivitas kerja adalah perbandingan antara output dengan input, di mana outputnya harus mempunyai nilai tambah dan teknik pengerjaannya yang lebih baik.

Berdasarkan pendapat di atas dapat disimpulkan bahwa produktivitas tenaga kerja sangat tergantung pada satuan masukan yang diberikan oleh tenaga kerja dan satuan keluaran yang dihasilkan oleh tenaga kerja tersebut. Satuan masukan dan satuan keluaran pada produktivitas tenaga kerja hanya tenaga kerja itu sendiri dan hasilnya.

Seorang tenaga kerja yang produktif adalah tenaga kerja yang cekatan dan menghasilkan barang dan jasa sesuai mutu yang ditetapkan dengan waktu yang lebih singkat atau bila tenaga kerja tersebut mampu menghasilkan produk atau output yang lebih besar dari tenaga kerja yang lain dalam waktu yang lama.Masalah produktivitas kerja tidak dapat terlepas dari hak setiap tenaga kerja untuk memperoleh kesempatan kerja demi kehidupan yang layak sebagai manusia. Hak untuk dapat menikmati kehidupan yang layak bagi tenaga kerja tidak mungkin dapat diperoleh tanpa jaminan atau upah yang cukup dengan didukung oleh adanya produktivitas tenaga kerja yang tinggi.

\section{Pengukuran Produktivitas Kerja}

Pengukuran produktivitas tenaga kerja menurut sistem pemasukan fisik per orang atau per jam kerja orang diterima secara luas, namun dari sudut pandangan/ pengawasan harian, pengukuranpengukuran tersebut pada umumnya tidak memuaskan, dikarenakan adanya variasi dalam jumlah yang diperlukan untuk memproduksi satu unit produk yang berbeda. Oleh karena itu, digunakan metode pengukuran waktu tenaga kerja (jam, hari 
atau tahun). Pengeluaran diubah ke dalam unit-unit pekerja yang biasanya diartikan sebagai jumlah kerja yang dapat dilakukan dalam satu jam oleh pekerja yang terpercaya yang bekerja menurut pelaksanaan standar, karena hasil maupun masukan dapat dinyatakan dalam waktu, produktivitas tenaga kerja dapat dinyatakan sebagai suatu indeks yang sangat sederhana = Hasil dalam jam-jam yang standar : Masukan dalam jam-jam waktu.

Pengukuran suatu produktivitas perusahaan dapat digunakan dua jenis ukuran jam kerja manusia, yakni jam-jam kerja yang harus dibayar dan jam-jam kerja yang dipergunakan untuk bekerja. Jam kerja yang harus dibayar meliputi semua jam-jam kerja yang harus dibayar, ditambah jam-jam yang tidak digunakan untuk bekerja namun harus dibayar, liburan, cuti, libur karena sakit, tugas luar dan sisa lainnya. Jadi bagi keperluan pengukuran umum produktivitas tenaga kerja kita memiliki unit-unit yang diperlukan, yakni: kuantitas hasil dan kuantitas penggunaan masukan tenaga kerja (Sinungan, 2008).

\section{METODE PENELITIAN}

\section{Objek Penelitian}

Dalam penelitian ini yang menjadi objeknya adalah PT. Masakini Mandiri di Bandar Lampung yang beralamatkan di Jl. Soekarno-Hatta No. 108 Bandar Lampung. Pelaksanaan penelitian mulai bulan Februari-Juni 2016.

\section{Metode dan Teknik Pengumpulan Data}

Metode penelitian yang akan penulis gunakan adalah deskriptif kausal, yaitu penelitian yang bertujuan untuk menguraikan sifat atau karakteristik dari suatu fenomena tertentu serta menganalisis hubungan-hubungan antara suatu variabel dengan variabel lainnya atau bagaimana variabel-variabel tersebut mempengaruhi variabel lainnya.Penelitian ini hanya dibatasi pada pengaruh karakteristik individu terhadap produktivitas karyawan bagian redaksi pada PT. Masakini Mandiri.

Dalam penelitian ini jenis data yang diperlakukan adalah :

a. Data Primer

Data primer merupakan data dasar yang akan diperoleh langsung tanpa perantara orang atau lembaga lain sebagai pihak ketiga. Data primer ini diperoleh dengan wawancara melalui responden dengan menggunakan daftar pertanyaan.

\section{b. Data Sekunder}

Data skunder merupakan data yang diperoleh melalui orang lain yang berhubungan dengan permasalahan yang dipecahkan. Data sekunder ini diperoleh melalui cara studi dokumenter yaitu mengumpulkan dan mempelajari brosurbrosur serta dokumen organisasi.

\section{Sampel dan Populasi}

Menurut Arikunto, apabila subjeknya kurang dari 100, maka lebih baik diambil semua sehingga penelitiannya merupakan penelitian populasi (Arikunto, 2008). Populasi dalam penelitian ini adalah seluruh karyawan bagian redaksi pada PT. Masakini Mandiri yang keseluruhannya berjumlah 52 orang. Melihat jumlah populasi yang relatif kecil yaitu kurang dari 100, maka penelitian ini mengambil seluruh karyawan bagian redaksi sebagai responden. Skala pengukuran untuk variabel karakteristik individu (X) pada penelitian ini digunakan data nominal.

\section{Metode Analisis Data}

Analisis secara kualitatif yaitu analisis terhadap pengaruh karakteristik individu terhadap produktivitas karyawan, selanjutnya diuraikan dalam bentuk kalimat 
yang tersusun secara sistematis dengan pendekatan teori manajemen sumber daya manusia khususnya teori karakteristik individu dan produktivitas karyawan.

Untuk mengetahui ada atau tidaknya pengaruh antara karakteristik individu terhadap produktivitas karyawan bagian redaksi pada PT. Masakini Mandiri, maka akan dibuktikan dengan menggunakan alat analisis regresi dengan menggunakan rumus linier berganda. Persamaan regresi linear berganda yang dirumuskan adalah sebagai berikut:

$$
Y=a+b_{1} X_{1}+b_{2} X_{2}+b_{3} X_{3}+b_{. .} X_{. .}+E t
$$

Keterangan :

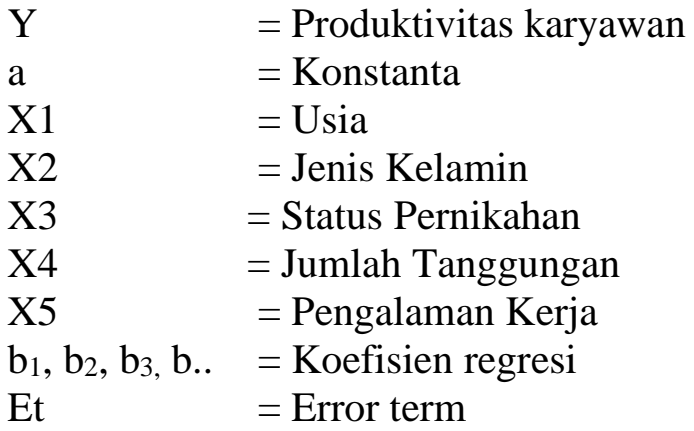

Untuk mengetahui besarnya pengaruh, penghitungan koefisien korelasi tersebut kemudian dilanjutkan dengan Rumus Koefisien Determinasi atau Koefisien Penentu (KP):

$$
K P=(r)^{2} x 100 \%
$$

Untuk menguji secara hipotesis secara parsial digunakan Uji t dengan rumus :

$$
t_{\text {hitung }}=\frac{r \sqrt{N-2}}{\sqrt{1-r^{2}}}
$$

Keterangan:

$$
\begin{array}{ll}
\mathrm{t}_{\text {hitung }} & =\text { Nilai } \mathrm{t} \\
\mathrm{r} & =\text { Koefisien Korelasi } \\
\mathrm{N} & =\text { Jumlah responden }
\end{array}
$$

Kriteria pengujiannya :

a. Ho ditolak dan Ha diterima jika thitung $>$ t table

b. Ho diterima dan Ha ditolak jika t hitung $<$ t tabel.

Hipotesis :

a. Ho : bi $=0$ (tidak ada pengaruh karakteristik individu terhadap produktivitas kerja karyawan bagian redaksi pada PT. Masakini Mandiri )

b. Ha : bi $\neq 0$ (ada pengaruh nyata karakteristik individu terhadap produktivitas kerja karyawan bagian redaksi pada PT. Masakini Mandiri).

Kemudian dilakukan dengan uji $\mathrm{F}$ pada tingkat kepercayaan 95\% dengan derajat kebebasan $\left(\mathrm{d}_{\mathrm{fl}}\right)=\mathrm{k}-1$ dan $(\mathrm{df} 2)=\mathrm{n}-\mathrm{k}$. Hipotesis yang dirumuskan :

a. Ho : bi $=0$ (tidak ada pengaruh karakteristik individu terhadap produktivitas kerja karyawan bagian redaksi pada PT. Masakini Mandiri)

b. Ha : bi $\neq 0$ (ada pengaruh nyata karakteristik individu terhadap produktivitas kerja karyawan bagian redaksi pada PT. Masakini Mandiri).

Kriteria pengujiannya :

a. Ho ditolak dan Ha diterima jika f hitung $>$ f tabel

b. Ho diterima dan Ha ditolak jika f hitung $<$ f tabel.

\section{HASIL DAN PEMBAHASAN}

\section{Analisis Kualitatif}

Berdasarkan hasil analisis kualitatif dapat diketahui mengenai tanggapan responden yaitu karyawan PT Masa Kini Mandiri Bagian Redaksi mengenai Produktivitas karyawan. Salah satu 
indikator dari produktivitas karyawan terlihat dari prestasi kerja karyawan, yang dalam pernyataan kuesioner diwakili pada pernyataan nomor 1 dan 2 . Penilaian responden mengenai hal ini adalah cukup baik, ini terlihat dari pernyataan nomor 1 mengenai pencapaian prestasi kerja yang baik di tempat kerja, responden berpendapat setuju dengan pernyataan tersebut dengan hasil persentase sebesar 40,4\%. Responden juga setuju dengan pernyataan nomor 2 mengenai penyelesaian tugas-tugas karyawan dengan baik yaitu dengan persentase sebesar $50 \%$.

Indikator produktivitas karyawan juga dapat terlihat dari kualitas kerja, yang dalam pernyataan kuesioner diwakili pada pertanyaan nomor 3,4 dan 5. Penilaian responden mengenai hal ini adalah cukup baik, ini terlihat dari pernyataan nomor 3 mengenai melakukan pekerjaan dengan akurat dan teliti., responden berpendapat setuju dengan pernyataan tersebut dengan hasil persentase sebesar $55,8 \%$, pertanyaan no 4 mengenai karyawan memberikan laporan kerja dengan lengkap dan benar dengan hasil persentase sebesar 59,6\% , responden juga setuju dengan pernyataan nomor 5 bahwa karyawan kualitas output pekerjaan saya sudah sesui dengan perintah atasan, yaitu dengan persentase sebesar $40,4 \%$.

Kuantitas kerja adalah salah satu indikator dari produktivitas karyawan, yang dalam pernyataan kuesioner diwakili pada pernyataan nomor 6,dan 7. Penilaian responden mengenai hal ini adalah netral, ini terlihat dari pernyataan nomor 6 bahwa Jumlah output yang dihasilkan sesuai dengan target perusahaan (60 tulisan/ bulan), responden berpendapat netral dengan pernyataan tersebut dengan hasil persentase sebesar 50\% hal ini dikarenakan terkadang responden mampu mencapai target dan juga terkadang tidak mampu mencapai target output 60 tulisan/ bulan, pada pertanyaan nomor 7 mengenai pencapaian hasil pekerjaan saya secara keseluruhan telah sesuai dengan standar yang ditetapkan perusahaan, responden menjawab setuju, yaitu dengan persentase sebesar $38,5 \%$.

Produktivitas karyawan juga tercermin dari disiplin kerja karryawan, yang dalam pernyataan kuesioner diwakili pada pertanyaan nomor 8 dan 9. Penilaian responden mengenai hal ini adalah netral, ini terlihat dari pernyataan nomor 8 bahwa responden selalu datang tepat waktu dalam bekerja, responden berpendapat netral, hal ini disebakan karena karywan bagian redaksi tidak selalu datang ke tempat kerja, namun hasil tulisan mereka bisa dikirim lewat e-mail, dengan hasil persentase sebesar 46,2\%. Responden setuju dengan pernyataan nomor 9 atau pertanyaan terakhir bahwa responden selalu taat dan patuh terhadap peraturan yang ada di dalam perusahaan yaitu dengan persentase sebesar $51,9 \%$.

\section{Analisis Kuantitatif}

Berdasarkan hasil perhitungan didapatkan persamaan untuk karakteristik individu (usia, jenis kelamin,status pernikahan, jumlah tanggungan, dan pengalaman kerja) $\mathrm{Y}=53,314+0,454 \mathrm{x}_{1}+$ $0,386 x_{2}+0,273 x_{3}+0,100 x_{4}+0,545 x_{5}$. Pengaruh karakteristik individu karyawan terhadap produktivitas karyawan dilihat dari nilai koefisien determinasi ( $R$ Square) sebesar 0,401 atau $40,1 \%$ dan selebihnya $67,4 \%$ dipengaruhi oleh faktor lain di luar penelitian ini.

Berdasarkan pada hasil perhitungan regresi liner berganda mengenai pengujian hipotesis secara keseluruhan, maka diperoleh hasil bahwa uji f hitung $(4,312)$ lebih besar $(>)$ dari f tabel, $(2,40)$ dengan demikian uji $\mathrm{f}$ membuktikan bahwa Ho ditolak dan $\mathrm{Ha}$ diterima. Hal ini berarti secara keseluruhan adalah "ada pengaruh karakteristik individu terhadap 
produktivitas karyawan bagian PT Masa Kini Mandiri”.

Penelitian ini sesuai dengan penelitian Sari (2009) tentang hubungan karakteristik individu dengan kinerja karyawan melalui komitmen organisasi sebagai variabl mediasi pada PT Masa Kini Mandiri, yang memperoleh nilai korelasi sebesar 33,1\%.

Usia $\left(\mathrm{X}_{1}\right)$ seorang karyawan memiliki peranan dalam menunjang produktivitas karyawan tersebut. Karyawan yang tergolong dalam usia yang produktif akan memberikan memberikan kotribusi positif terhadap produktivitas kerjanya. Hasil penelitian ini menunjukkan usia memiliki pengaruh besar, yaitu 0,454 terhadap produktivitas kerja karyawan.

Jenis kelamin $\left(\mathrm{X}_{2}\right)$ seorang karyawan dalam penelitian ini memiliki pengaruh paling kecil, yaitu sebesar 0,386 terhadap produktivitas kerja. Hal ini disebabkan karena dalam bagian redaksi, para karyawan bekerja cenderung menggunakan kemampuan berfikir daripada kemampuan fisik.

Status pernikahan $\left(\mathrm{X}_{3}\right)$ karyawan membuat karyawan yang sudah menikah akan lebih bergantung terhadap perusahaan jika dibandingkan dengan karyawan yang belum menikah. Perkawinan memaksakan peningkatan tanggung jawab yang membuat suatu pekerjaan yang tetap menjadi lebih berharga dan penting. Seseorang yang telah menikah merasa lebih mantap dengan pekerjaannya yang sekarang, hal ini dikarenakan bahwa mereka melihat sebagai jaminan untuk masa depannya. Hasil penelitian ini menunjukkan pengaruh status pernikahan yaitu 0,273 terhadap produktivitas karyawan.

Jumlah tanggungan $\left(\mathrm{X}_{4}\right)$ memiliki pengaruh yang paling kecil, yaitu 0,100 terhadap produktivitas kerja karyawan. Karyawan yang sudah memiliki pengalaman kerja $\left(\mathrm{X}_{5}\right)$ akan membentuk keahlian di bidangnya, sehingga dalam menyelesaikan suatu pekerjaan akan cepat selesai. Semakin lama pengalaman kerja seorang karyawan akan semakin mudah dalam menyelesaikan pekerjaannya. Karyawan yang sudah memiliki pengalaman kerja yang cukup lama dalam bidang redaksi akan lebih cepat menyelesaikan pekerjaannya jika dibandingkan dengan karyawan yang baru bekerja. Hasil penelitian ini menunjukkan pengalaman kerja memiliki pengaruh paling besar, yaitu 0,545 terhadap produktivitas kerja karyawan.

Berdasarkan hasil uji regresi menunjukan variabel pengalaman kerja dan usia paling besar berpengaruh terhadap produktivitas kerja karyawan bagian redaksi PT Masa Kini Mandiri. Selanjutnya di ikuti variabel jenis kelamin, status pernikahan, dan jumlah tanggungan. Berdasarkan hasil penelitian ini penting bagi pimpinan redaksi PT Masa Kini Mandiri memperhatikan pengalaman kerja dan usia karyawannya dalam upaya meningkatkan produktivitas karyawan bagian redaksi PT Masa Kini Mandiri.

\section{KESIMPULAN DAN SARAN}

\section{Kesimpulan}

Berdasarkan pembahasan dan analisis perhitungan membuktikan bahwa ada pengaruh yang positif antara karakteristik individu karyawan terhadap produktivitas karyawan bagian redaksi PT Masa Kini Mandiri, hal ini didasarkan pada:

1. Persamaan regresi berganda yaitu : $\mathrm{Y}=53,314+0,454 \mathrm{x}_{1}+0,386 \mathrm{x}_{2}+0,273 \mathrm{x}_{3}+0$, $100 \mathrm{x}_{4}+0,545 \mathrm{x}_{5}$

2. Hasil uji hipotesis menunjukan karakteristik individu karyawan (X) memiliki nilai $\mathrm{t}$ hitung > nilai $\mathrm{t}$ tabel, maka ho ditolak dan ha diterima

3. Nilai koefisien determinasi ( $R$ Square) sebesar 0,401 atau $40,1 \%$ dan selebihnya $59,9 \%$ dipengaruhi oleh faktor lain di luar penelitian ini 
4. Hasil bahwa uji $\mathrm{f}$ hitung $(4,312)$ lebih besar $(>)$ dari $\mathrm{f}$ tabel, $(2,55)$ dengan demikian uji f membuktikan bahwa Ho ditolak dan Ha diterima.

\section{Saran}

Saran dari penelitian ini yang dapat menjadi alternatif untuk meningkatkan produktivitas karyawan bagian redaksi pada PT Masa Kini Mandiri, yaitu:

1. Karyawan terkadang datang tepat waktu terkadang tidak tepat waktu, untuk itu disarankan kepada perusahaan untuk menghimbau kepada karyawan agar datang tepat waktu.

2. Karakteristik individu karyawan bagian redaksi PT Masa Kini Mandiri yang paling besar mempengaruhi produktivitas kerja karyawan adalah usia dan pengalaman kerja, untuk itu perusahaan perlu memperhatikan mengenai usia dan pengalaman kerja karyawan.

\section{DAFTAR PUSTAKA}

Arikunto, Suharsimi. 2008. Prosedur Penelitian Suatu Pendekatan Praktik. Edisi Revisi Keenam. Jakarta: PT Rineka Cipta.

Hasibuan, Malayu S.P. 2008. Manajemen Sumber Daya Manusia. Edisi Revisi. Cetakan Kedua belas. Jakarta: PT Bumi Aksara.

Jahrie dan Hariono. 2008. Human Resourse Management. Edisi Pertama. Cetakan Pertama. Jakarta: Asosiasi Institut Manajemen Indonesia.

Istijanto. 2008. Riset Sumber Daya Manusia. Cetakan Ketiga. Jakarta: PT Gramedia Pustaka Utama.
Kreitner, Robert dan Angelo Kinicki.2004. Perilaku Organisasi. Jakarta: Salemba Empat.

Mathis, Robert L. and John H. Jackson. 2006. Human Resource Management. Edisi Kesepuluh. Jakarta: Salemba Empat.

Mangkuprawira, Tb. Sjafri. 2003. Manajemen Sumber Daya Manusia Strategik. Cetakan Kedua. Jakarta: Ghalia Indonesia.

Nitiseminto S, Almisal, 2008. "Manajemen Personalia", Jakarta : Ghalia Indonesia.

Ravianto. 2007. Produktivitas dan manajemen. Jakarta: PT Bumi Aksara.

Rivai, Veithzal. 2006. Manajemen Sumber Daya Manusia Untuk Perusahaan: Dari Teori Ke Praktik. Jakarta: Murai Kencana.

Sari, Sulistia. 2009. Hubungan Karakteristik Individu dengan Kinerja Karyawan Melalui Komitmen Organisasi Sebagai Variabel Mediasi pada PT. Chandra Superstore Tanjung Karang. Skripsi. Universitas Lampung.

Siagian, Sondang.P.2008. Manajemen Sumber Daya Manusia. Jakarta: PT. Bumi Aksara.

Supranto, J. 2001. Statistik : Teori dan Aplikasi. Edisi Keenam. Jilid Kedua. Jakarta: Erlangga. 